\begin{tabular}{|c|c|c|c|c|}
\hline Paläont. Z. & $\mathbf{5 5}$ & $3 / 4$ & $313-319$ & Stuttgart, Dezember 1981 \\
\hline
\end{tabular}

\title{
A teleosaurid (Crocodylia, Mesosuchia) from the Toarcian of Madagascar and its palaeobiogeographical significance
}

\author{
Eric Buffetaut, Geneviève Termier \& Henri Termier, Paris*
}

With 2 figures in the text

Kurzfassung: Ein Oberkieferfragment eines Krokodiliers aus dem Toarcium von NW-Madagaskar wird als Stenosaurus sp. (Familie Teleosauridae) bestimmt. Es ist der älteste aus Madagaskar bekannte Krokodilier und deutet aunistische Beziehungen mit Westeuropa und Südamerika an. Die Verbreitung der oberliassischen marinen Krokodilier, die derjenigen des Ammoniten Bouleiceras ähnelt, weist auf die Existenz einer epikontinentalen Seestraße von der Tethys über die transerythräische Provinz bis zum südlichen Teil Afrikas; diese Seestraße bildete eine Verbindung zwischen Westeuropa und Südamerika.

A bstract : A fragment of the upper jaw of a crocodilian from the Toarcian of NW Madagascar is referred to Steneosaurus sp. (family Teleosauridae). It is the earliest known crocodilian from Madagascar. It indicates faunal relationships with western Europe and South America. The distribution of late Liassic marine crocodilians, similar to that of the ammonite Bouleiceras, suggests the existence of an epicontinental seaway from the Tethyan region to the southern part of Africa via the Transerythrean Province, which provided a marine connection between western Europe and South America.

Résumé : Un fragment de mâchoire supérieure de Crocodilien du Toarcien du NW de Madagascar est rapporté à Steneosaurus sp. (famille Teleosauridae). C'est le plus ancien Crocodilien connu à Madagascar. Il indique des relations fauniques avec l'Europe occidentale et l'Amérique du Sud. La répartition des Crocodiliens marins du Lias supérieur, similaire à celle de l'ammonite Bouleiceras, suggère l'existence d'un bras de mer épicontinental s'étendant de la Téthys au Sud de l'Afrique, via la Province Transérythréenne, ce qui réalisait une connexion marine entre l'Europe occidentale et l'Amérique du Sud.

\section{Introduction}

The specimen described here is not the first teleosaurid crocodilian to be reported from the Jurassic of Madagascar (see below), but it is the earliest representative of that family to be known from this island. Moreover, this crocodilian jaw fragment has some interesting palaeobiogeographical implications, bearing on the extent and location of epicontinental seaways in the early Jurassic, which complement the data already yielded by the distribution of marine invertebrates.

\footnotetext{
"Addresses of the authors: Dr. E. BuffEtaut, C.N.R.S., Laboratoire de Paléontologie des Vertébrés, Université Paris VI, 4 place Jussieu, 75230 Paris Cedex 05; Dr. G. Termier, Prof. Dr. H. Termier, 131 avenue de Versailles, 75016 Paris.
} 


\section{Geological occurrence}

The jaw fragment described here was found by two of us (G.T. and H. T., guided to the locality by Eugìne Razafimbelo) at Behazonaty, SW of the basin of the Kelifely, in the Majunga region (north-western part of Madagascar). It was collected from a ferruginous hard-ground in marly limestones containing the ammonite Nejdia. This horizon (D2 of BLAIsON 1963) is referred to the middle or late Toarcian, and overlies the Bouleiceras and Spiriferina beds of the early Toarcian. Both levels also yield bivalves from the tidal zone (Trigonia, Modiolus), and sometimes show indications of supratidal and lagoonal environments (with gypsiferous clays); they also contain bone fragments and lignites, and are divided by hard-grounds.

This series belongs to the Kandreho Formation (Collignon et al. 1959), which is the Malagasy equivalent of the Marrat Formation of Saudi Arabia (Jebel Tuwaiq). The corresponding province is known as the Transerythrean Province, which began with the Tuwaiq Gulf (ARKELL et al. 1952).

\section{Description}

The upper jaw fragment found at Behazonaty (in the collections of the Institut Géologique Albert de Lapparent, Paris) consists of a relatively small part of the maxillae, which meet ventrally and dorsally in the mediosagittal plane (Fig. 1). Neither the premaxillae nor the nasals are present between them on the dorsal surface. There was thus no contact between the premaxillae and the nasals. This is a well-known feature of the Jurassic long-snouted mesosuchian crocodiles of the families Teleosauridae and Metriorhynchidae (however, the premaxillae and the nasals met secondarily in some of the more brevirostrine metriorhynchids). The dorsal surface of the maxillae is covered with widely spaced small oval pits. In ventral view, three complete alveoli are visible on the right side, and four on the left one. The alveoli have circular openings and are fairly large; their diameters increase slightly from front to back (the mediolateral diameters of the most anterior alveolus on the left side is $11 \mathrm{~mm}$, that of the fourth one $15 \mathrm{~mm}$ ). The alveoli are separated by short intervals (5 to $10 \mathrm{~mm}$ ); their external margins protrude slightly laterally.

Between the alveoli, the palate is nearly flat, with only a slight depression along the median suture. The alveoli open in a plane slightly oblique as compared with that of the palate.

In cross-section, the snout appears regularly rounded dorsally, so that its outline is more or less semi-circular. The nasal passage is clearly visible; its section is of bilobate shape, because of a well-marked median ridge along the median suture between the maxillae. The volume of this passage is relatively reduced by the large spaces occupied dorsolaterally by the alveoli.

In lateral view, the height of the snout increases slightly but definitely from front to back (just as the width of the specimen also increases slightly anteroposteriorly). The openings of the alveoli are also visible in lateral view; it thus appears that the teeth were directed downwards and slightly forwards and outwards.

Measurements:

Length of specimen: $100 \mathrm{~mm}$; Maximum width: $62 \mathrm{~mm}$; Anterior height: $27 \mathrm{~mm}$; Posterior height: $32 \mathrm{~mm}$.

\section{Affinities}

Two families of long-snouted crocodilians without a contact between the premaxillae and the nasals are known from the Jurassic: the Teleosauridae and the Metriorhynchidae, which can be united in an infraorder of the Mesosuchia, the Thalattosuchia FraAs (Bufferaut 1980). The 
specimen from Behazonaty obviously belongs to one of these families. Comparison with European specimens reveals considerable resemblances with the genus Steneosaurus Geofrror SAINT-Hilaire, 1825, especially in the general shape of the snout and in the position and orientation of the alveoli. The lack of deep longitudinal grooves on the palate seems to exclude our specimen from the Metriorhynchidae. We therefore refer it to a teleosaurid of the genus Steneosaurus; however, no attempt at a specific identification can be made on the basis of such fragmentary material, and we thus designate it as Steneosaurus sp.

The genus Steneosaurus has already been reported from Madagascar (for a short review of fossil crocodilians from Madagascar, see Buffetaut \& TAQuet 1979). As early as 1892, R. B. Newton described as Steneosaurus baroni a partial skull with lower jaw found by the Rev. BARON in the Bathonian of Andranosamonta, in the north-western part of the island. Additional teleosaurid remains possibly referable to $S$. baroni were later reported from the Bathonian of the south-western part of Madagascar by BASsE (1934), but they were not described in detail (see also BAsSE DE MÉnorval 1963). The exact relationships between the Toarcian form and Steneosaurus baroni can hardly be ascertained on the basis of the available material; it is however likely that they were both fairly large representatives of Steneosaurus (the length of the skull of $S$. baron $i$ was estimated at about $80 \mathrm{~cm}$ ). The Toarcian specimen shows that Steneosaurus was already present in Madagascar at an early date. The earliest known representatives of this genus in other parts of the world are also of late Liassic age (see below), the best specimens coming from the Toarcian of Europe. Teleosaurid remains from deposits older than the Toarcian are very scarce. There are very scanty remains from the Domerian of eastern France (Huene \& Maubeuge 1954), as well as from the Sinemurian of Chile (CHONG \& GASPAR INI 1972), but little can be said concerning their affinities. Teleosaurid remains have also been reported from the early Liassic Kota Formation of India (OwEN 1852), but according to JAIN (1980) the Kota crocodile was probably a "short-nosed" one, which casts doubts on its attribution to the Teleosauridae. A full description of the newly-discovered Indian material will be needed in order to clarify the matter.

In any case, the occurrence of Steneosaurus in the Toarcian of Madagascar confirms that the genus already had a wide geographical distribution at an early stage of its history.

\section{Palaeobiogeographical significance}

The extensive geographical distribution of Steneosaurus in the Toarcian is easily explainable, since this crocodilian apparently possessed good swimming abilities (KREBS 1962) and was adapted to marine life, even though it still spent part of its time on land (Westrhal 1962). Actually, the rather sudden appearance of numerous Steneosaurus remains in marine deposits of Toarcian age is probably linked to the "conquest" of coastal environments by the Teleosauridae, which in all likelihood had previously evolved mainly in continental areas (WESTPHAL 1962), the early stages of their evolution being almost unknown because of the extreme scarcity of continental vertebrate-bearing beds of early Liassic age. From a palaeobiogeographical point of view, there is no doubt that the Teleosauridae, and especially Steneosaurus, should be considered as marine organisms, even though they were still able to move on land. Their main migration routes were thus the Jurassic seas, and it is in this light that the Steneosaurus fragment from Behazonaty should be interpreted.

In the late Liassic, the genus Steneosaurus is known from Europe (Germany, England, France, Portugal), Madagascar (the specimen described here) and north-western Argentina (HuEne 1927). The remains from Madagascar and those from Argentina (two vertebrae) cannot be identified at the species level (although HuEne called the Argentine fossils Steneosaurus gertbi), but relationships at the generic level can be considered as significant from a biogeographical point of view. Considering what is known of Liassic world palaeogeography, with little frag- 
mentation of Pangaea, this distribution may at first sight seem strange, and the position and nature of possible migration routes for marine crocodilians in the Liassic are worth discussing.

An interesting biogeographical parallel can be found between the distribution of Steneosaurus and that of the ammonite Bouleiceras, which occurs in the early Toarcian of the Majunga region, just below the horizon which has yielded the teleosaurid fragment described here. Outside the Arabian-Malagasy region, the genus Bouleiceras is also known from Portugal (Mouterde 1953) and Spain (GEYER 1965); a fauna corresponding to the same province also occurs in Algeria and Morocco. It is thus possible to link the Tuwaiq Gulf to the region of the western "Mediterranean" in the late Liassic. Nejdia, which occurs in the same bed as the Behazonaty crocodilian, seems to be restricted to the Transerythrean Province. The occurrence of Steneosaurus in the same level as Nejdia thus allows to pursue the palaeogeographical correlation somewhat further in time. Moreover, Bouleiceras is also known to occur in the southern Andes of Chile and Argentina (HillebRANDT 1973). There is thus a remarkable correspondence between the geographical ranges of this ammonite and of the late Liassic Steneosaurus. Both distributions are apparently explainable by the existence of a marine connection from western South America around the southern tip of Africa to the Transerythrean Province and thence to the Tethyan area (Fig. 2). The existence of such a southern connection has been postulated by HaLLAM (1977) to explain the distributions of Jurassic ammonites (including Bouleiceras) and bivalves. The late Liassic distribution of Steneosaurus thus seems to be in agreement with Hallam's proposal of a southern marine connection, which is also accepted by ENAY (1980). However, it should be re-

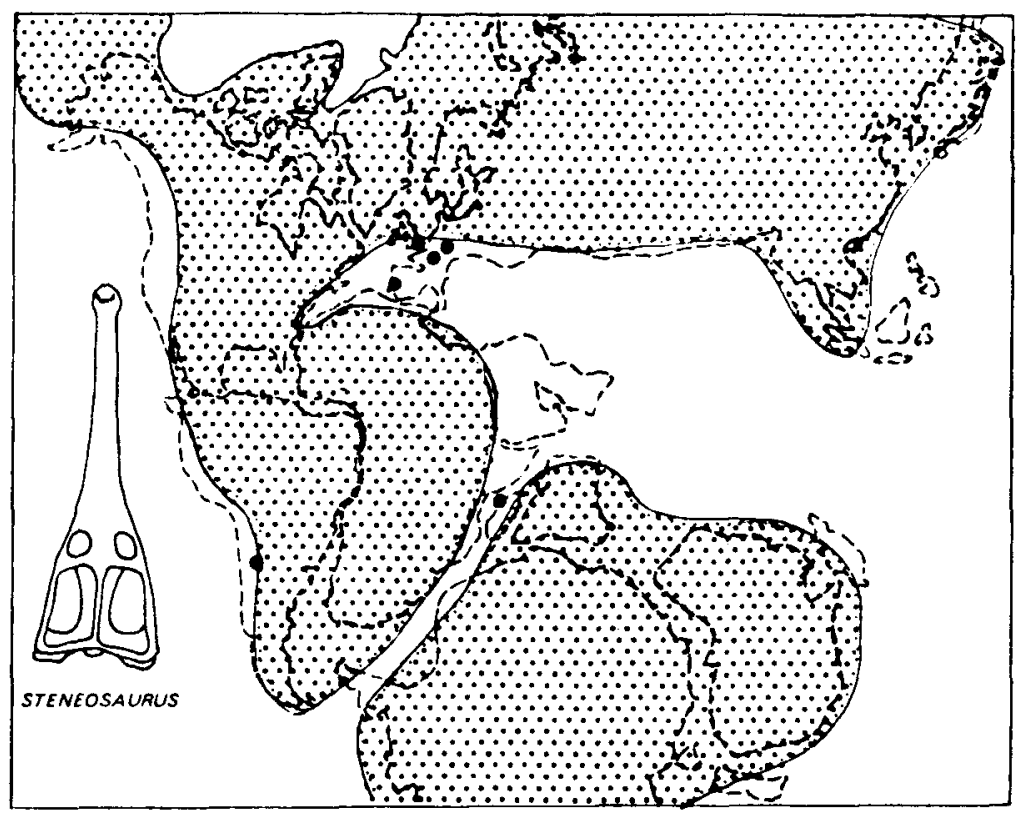

Fig. 2. Palaeogeographical map for the Toarcian, showing the distribution of the marine teleosaurid crocodilian Steneosaurus (black dots). Position of the continents after SMITH \& BRIDEN (1977), distribution of land (stippled) and sea after Hallam (1977). From Buffetaut (1981).

Abb. 2. Paläogeographie des Toarciums. Große schwarze Punkte: Vorkommen des marinen Teleosauriden Steneosaurus; Lage der Kontinente nach SMITH \& BRIDEN (1977), Verteilung von Land (punktgerastert) und Meer (weiß) nach Hallam (1977). Aus Buffetaut (1981). 

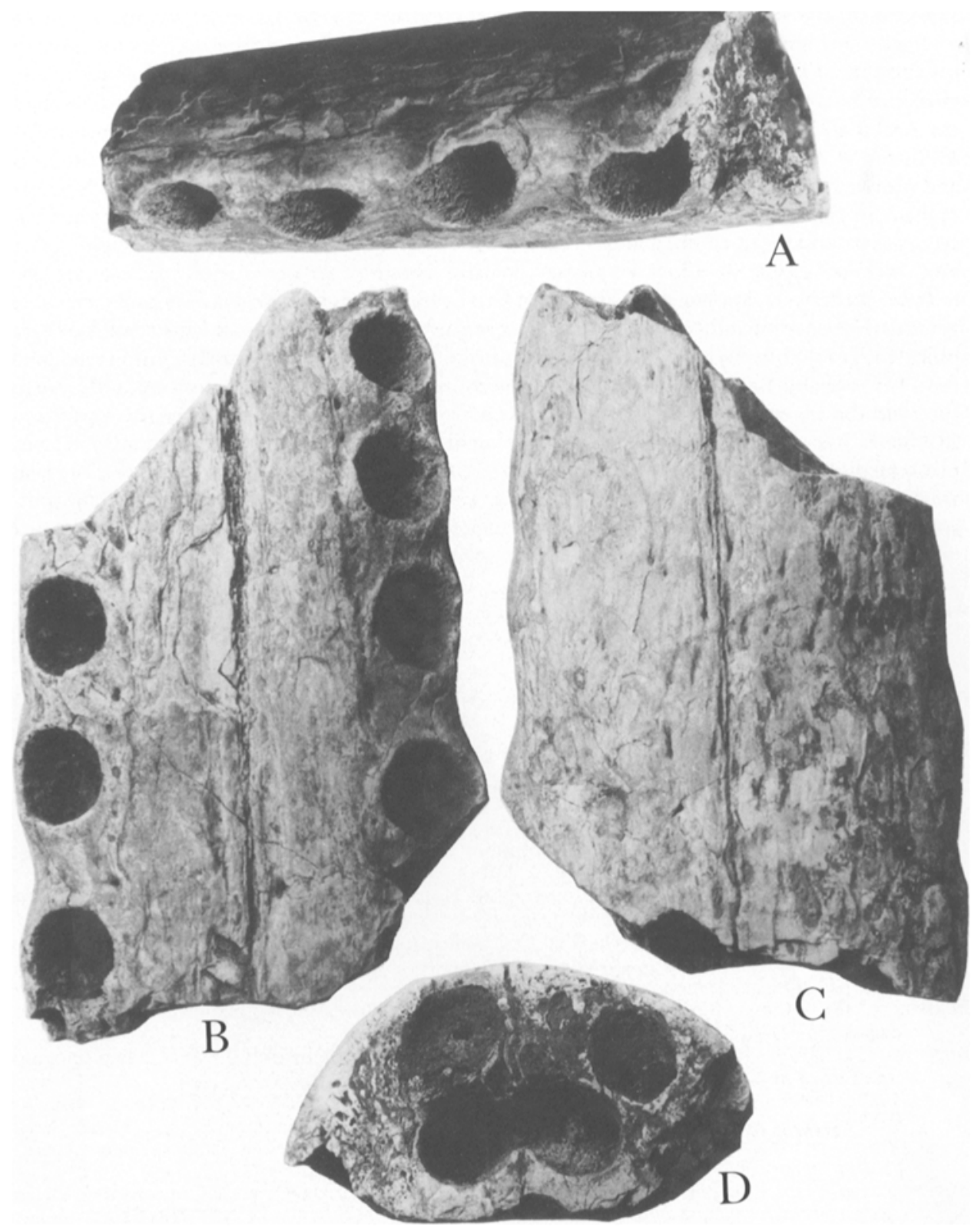

Fig. 1. Upper jaw fragment of Steneosaurus sp. from the Toarcian of Behazonaty, NW Madagascar. Institut Géologique Albert de Lapparent, Paris. A: left lateral view; B: ventral view; C: dorsal view; D: posterior view; $\times 1$.

Abb. 1. Oberkiefer-Fragment von Steneosaurus sp. aus dem Toarcium von Behazonaty, NW-Madagaskar; $\times 1$. 
membered that our knowledge of marine crocodilians of that age is still incomplete; the recent discovery of teleosaurids in the middle Jurassic of Oregon (BuffETAUT 1979), while this family was previously unknown in North America, illustrates the fact that unexpected new discoveries could well modify our ideas on the biogeography of Jurassic marine crocodilians. Nevertheless, according to Hallam's palaeogeographical reconstruction for the Pliensbachian and Toarcian (HALLAM 1977), there was no direct marine connection at this stage between western Europe and the West coast of the Americas, so that the likeliest migration route for teleosaurids was through the Transerythrean Province and around the southern tip of Africa and South America (or in the opposite direction, depending on the place of origin of the group which is unknown). Dispersal around the northern end of North America could also be envisioned, but is less likely, since there are no records of Liassic teleosaurids from North America or the North Polar region.

The nature of the seaway extending from the Tethyan region to Madagascar and beyond is also worth discussing, since recent palaeogeographical reconstructions (for instance SMITH $\&$ BRIDEN 1977) do not indicate a separation of the continental blocks of eastern Gondwanaland (Africa, Madagascar, India, Antarctica, Australia), by way of sea-floor spreading, until much later than the Liassic. SHIELDS (1977) suggests a Cenomanian-Turonian age for the separation between Kenya and Madagascar, and the opening of the Red Sea is of course much more recent. It thus appears, as pointed out by HaLlam (1977), that the seaway extending from the Tethyan domain to the south-eastern part of Africa, in the Liassic must have been an epicontinental strait. According to HALLAM this strait probably originated in the early Toarcian, as a result of a global transgression, and persited during the whole of the Jurassic. An interesting point is that, in HALLAM's words (1977: 30), "the seaway apparently marks the site of later sea-floor spreading, when the fragments of Gondwana began to disperse in the Cretaceous". However, the details of the establishment of this epicontinental connection have yet to be worked out; as shown by FÖRSTER's work on the sedimentary basin of southern Mozambique (FörSTER 1975), the geological history of the Transerythrean Province was probably a complicated one.

\section{Literature}

ARKell, W. J. (1952): Jurassic ammonites from Jebel Tuwaiq, Central Arabia; with stratigraphical Introduction by R. A. Bramkamp and M. Steineke. - Phil. Trans. Roy. Soc. London, B, 633, 236: 241-313; London.

Basse, E. (1934): Etude géologique du Sud-Ouest de Madagascar. - Mém. Soc. géol. France, n. s., t. 10, 24 : 1-157; Paris.

Basse de Ménorval, E. (1963): Présence d'un Crocodilien Steneosaurus cf. obtusidens Andrews dans le Rauracien supérieur (couches à Trigonia clavellata) des environs de Verdun (Meuse). - C. R. somm. Soc. géol. France, 3: 86-87, Paris.

Blaison, J. (1963): Observations nouvelles sur la stratigraphie du Jurassique de la région de Kandreho (Madagascar). - Bull. Soc, géol. France, (7) 5: 969-979; Paris.

Buffetaut, E. (1979): Jurassic marine crocodilians (Mesosuchia: Teleosauridae) from Central Oregon: first record in North America. - J. Paleont., 53 (1): 210-215; Tulsa.

- (1980): Teleosauridae et Metriorhynchidae: l'évolution de deux familles de Crocodiliens mésosuchiens marins du Mésozoïque. - C.R.105e Congr. nat. Soc. Sav. (Caen), Sciences, 3: 11-22; Paris.

- (1981): Die biogeographische Geschichte der Krokodilier, mit Beschreibung einer neuen Art, Araripesuchus wegeneri. - Geol. Rundschau, 70 (2): 611-624; Stuttgart.

Buffetaut, E. \& Taquet, P. (1979): Un nouveau Crocodilien mésosuchien dans le Campanien de Madagascar: Trematochampsa oblita, n. sp. - Bull. Soc. géol. France (7), 21: 183-188; Paris.

Chong, G. \& Gasparini, Z. B. De (1972): Presencia de Crocodilia marinos en el Jurasico de Chile. - Rev. Asoc. geol. Argent., 27 (4): 406-409; Buenos Aires.

Collignon, M.; Rebilly, G. \& Roch, E. (1959): Le Lias et le Jurassique moyen de la région de Kandreho (Madagascar). - Bull. Soc. géol. France (7), 1: 132-136; Paris.

ENAY, R. (1980): Paléobiogéographie et Ammonites jurassiques: «rythmes fauniques» et variations du niveau marin; voies d'échanges, migrations et domaines biogéographiques. - Mém. h. s. Soc. géol. France, 10 (Livre jubilaire): 261-281; Paris. 
FörSTER, R. (1975): The geological history of the sedimentary basin of southern Mozambique, and some aspects of the origin of the Mozambique Channel. - Palaeogeog. Palaeoclimat. Palaeoecol., 17: 267-287; Amsterdam.

Geyer, O. F. (1964): Einige Funde der arabo-madagassischen Ammoniten-Gattung Bouleiceras im Unterjura der iberischen Halbinsel. - Paläont. Z., 39, 1/2: 26-32; Stuttgart.

Hallam, A. (1977): Biogeographic evidence bearing on the creation of Atlantic seaways in the Jurassic. In: R. M. West (ed.): Paleontology and Plate Tectonics, Milwaukee Publ. Mus. Spec. Pub. Biol. Geol., 2: 23-34; Milwaukee.

Hillebrandt, A. von (1973): Die Ammonitengattungen Bouleiceras and Frechiella im Jura von Chile und Argentinien. - Ecolog. geol. Helvet., 66: 351-363; Basel.

Huene, F. von (1927): Beitrag zur Kenntnis mariner mesozoischer Wirbeltiere in Argentinien. -Centralbl. Min. Geol. Paläont. B, 1: 22-29; Stuttgart. .

Huene, F. von \& Maubeuge, P. L. (1954): Sur quelques restes de sauriens du Rhétien et du Jurassique lorrains. - Bull. Soc. géol. France (6), 4: 105-109; Paris.

JAIN, S. L. (1980): The continental Lower Jurassic fauna from the Kota Formation, India. - In: L. L. JACOBS (ed.): Aspects of vertebrate history, Museum of Northern Arizona Press, 99-123; Flagstaff.

Krebs, B. (1962): Ein Steneosaurus-Rest aus dem Oberen Jura von Dielsdorf, Kt. Zürich, Schweiz. Schweiz. paläont. Abh., 79: 1-28; Basel.

Mouterde, R. (1953): Une forme d'affinités arabo-malgaches, Bouleiceras, dans le Toarcien inférieur de Coimbra. - Bol. Soc. geol. Portugal, 11: 93-100, Lisboa.

Newton, R. B. (1893): On the discovery of a Secondary reptile in Madagascar: Steneosaurus Baroni (n. sp.). - Geol. Mag., n. s., 10: 193-198; London.

OweN, R. (1852): Note on the crocodilian remains accompanying Dr. T. L. BeLL's paper on Kotah. -Q. J. geol. Soc. London, 8: 233; London.

Shields, O. (1977): A Gondwanaland reconstruction for the Indian Ocean. - J. Geol., 85: 236-242; Chicago.

Smith, A. G. \& Briden, J. C. (1977): Mesozoic and Cenozoic Paleocontinental Maps. - Cambridge University Press, 63 p.; Cambridge.

West'phal, F. (1962): Die Krokodilier des deutschen und englischen oberen Lias. - Palaeontographica A, 118: 1-96; Stuttgart.

Eingang des Manuskripts bei der Schriftleitung am 10. 2. 1981. 